\title{
onmbalina
}

(8)

\section{'I spy stangers': jesuit plays and their travels}

\author{
Autor(es): $\quad$ Griffin, Nigel
}

Publicado por: Imprensa da Universidade de Coimbra

URL

persistente: URI:http://hdl.handle.net/10316.2/32340

DOI: $\quad$ DOI:http://dx.doi.org/10.14195/978-989-26-0482-4_2

Accessed : $\quad$ 26-Apr-2023 12:20:22

A navegação consulta e descarregamento dos títulos inseridos nas Bibliotecas Digitais UC Digitalis, UC Pombalina e UC Impactum, pressupõem a aceitação plena e sem reservas dos Termos e Condições de Uso destas Bibliotecas Digitais, disponíveis em https://digitalis.uc.pt/pt-pt/termos.

Conforme exposto nos referidos Termos e Condições de Uso, o descarregamento de títulos de acesso restrito requer uma licença válida de autorização devendo o utilizador aceder ao(s) documento(s) a partir de um endereço de IP da instituição detentora da supramencionada licença.

Ao utilizador é apenas permitido o descarregamento para uso pessoal, pelo que o emprego do(s) título(s) descarregado(s) para outro fim, designadamente comercial, carece de autorização do respetivo autor ou editor da obra.

Na medida em que todas as obras da UC Digitalis se encontram protegidas pelo Código do Direito de Autor e Direitos Conexos e demais legislação aplicável, toda a cópia, parcial ou total, deste documento, nos casos em que é legalmente admitida, deverá conter ou fazer-se acompanhar por este aviso. 
Sebastiāo Tavares de Pinho

Coordenação

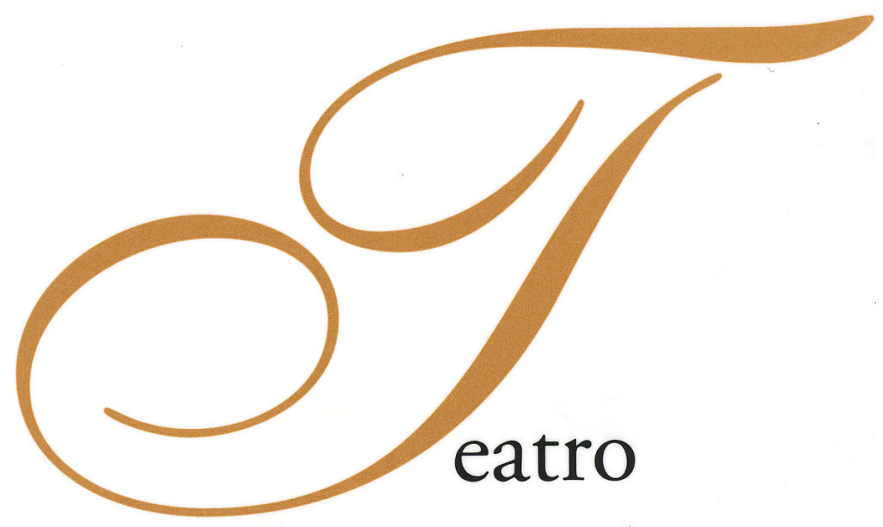

Neolatino em Portugal

no Contexto da Europa

450 Anos

de Diogo de Teive

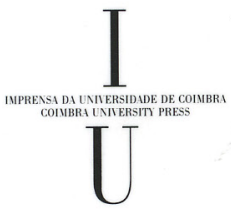

- COIMBRA 2006 
(Página deixada propositadamente em branco) 
C

U

M

E

$\mathrm{N}$

T

0

S

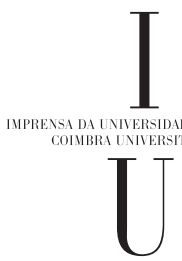




\section{COORDENAÇÃO EDITORIAL}

Imprensa da Universidade de Coimbra

URL: http//www.imp.uc.pt

\section{CONCEPÇÃo GRÁFICA}

António Barros

PRÉ-IMPRESSÃo

António Resende

Imprensa da Universidade de Coimbra

EXECUÇÃo GRÁFICA

SerSilito - Maia

ISBN

$972-8704-75-5$

DEPÓSITO LEGAL

(C) Junho 2006, Imprensa da Universidade de Coimbra

OBRA PUBLICADA COM O FINANCIAMENTO DE:

Centro de Estudos Clássicos e Humanísticos

FCT Fundação para a Ciência e a Tecnologia

MINISTÉRIO DA CIÊNCIA, TECNOLOGIA E ENSINO SUPERIOR Portugal

OBRA PUBLICADA COM O APOIO DE:

FCT: Fundação para a Ciência e Tecnologia • Ministério da Ciência e do Ensino Superior Apoio do Programa Operacional para a Ciência, Tecnologia, Inovação do III Quadro Comunitário de Apoio 
O TEATRO NeOlatino EM PORTUGal NO CONTEXTO DA EUROPA

450 AnOs DE DIOGO DE TEIVE 
(Página deixada propositadamente em branco) 


\author{
Nigel Griffin \\ Christ Church Oxford
}

'I SPY STRANGERS': JESUIT PLAYS AND THEIR TRAVELS

In the summer of 1566, the Jesuit college in the Southern German town of Dillingen was busily occupied with preparations for the arrival of a distinguished guest.

This Bavarian town, close to Augsburg and Munich and strategically located on the north bank of the Danube astride one of the much travelled routes between Vienna and Trent, had seen a steady stream of important political and ecclesiastical emissaries pass through its gates over the course of the 1550s and 1560s. Dillingen University, founded by the bishop of Augsburg and accorded official recognition in 1551 by Julius III, one of the two co-presidents of the opening sessions of the Council of Trent six years earlier, was the only new university created at this period in Southern Germany and it boasted a large, international, and swelling student population. (1)

(1) See the figures for 1550-60 in Franz EULENBERG, "Die Frequenz der deutschen Universitäten von ihrer Gründung bis zur Gegenwart", Abhandlung der Philosophisch-historische Klasse der Königliche Sächsichen Gesellschaft der Wissenschaften (Leipzig), XXIV (1904), 102-3. On the importance of the university and the college, see also Thomas SPECHT, Geschichte der ebemaligen Universität Dillingen (1549-1804) und der mit ibr verbundenen Lebr- und Erziebungs-Anstalten (Freiburg im Breisgau \& St Louis MO: Herder, 1902), 1043 56-8; Laetitia BÖHM, "Usus Dilingae: Modell oder Ärgernis?: Ein Besinnung auf die Bedeutung der ehemaligen Universität Dillingen als Glückwunsch zum ersten Jubiläum der Universität Augsburg», in Probleme der Integration Ostschwabens in den bayerischen Staat: Bayern und Wittelsbach in Ostschwaben: Referate und Beiträge der Tagung auf der Reisenburg am 21./22. März 1980, Veröffentlichungen der Schwäbischen Forschungsgemeinschaft bei der Kommission für Bayerische Landesgeschichte, Reihe 7: Augsburger Beiträge zur Landesgeschichte Bayerisch-Schwabens 2, ed. Pankraz FRIED (Sigmarigen: J. Thorbecke, 1982), 245-68; and Karl HENGST, Jesuiten an Universitäten und Jesuitenuniversitäten: Zur Geschichte der Universitäten in der Oberdeutschen und Rheinischen 
The Jesuit college had been licenced by Pius IV in 1561 to issue its own independent degrees but did not begin a full teaching programme until 1564; even then it had to wait until 1566 before it could hold its official opening ceremony. The college authorities were throughout the 1560 s heavily involved in the protracted piecemeal negotiations between the papacy, the German bishops, and various local independent princes, that did so much to decide the eventual religious affiliations of the towns and estates of the region. One weapon the Jesuit community had in its armoury when it wished to make common cause with those working on Rome's behalf was to mark the presence of important Catholic visitors to the town by staging public festivities in their honour. The four-monthly letters for 1564 , for example, are full of references to events held to mark the presence of distinguished guests, and a lengthy account dated 1 July 1565 describes some of these in detail. Such depatches reveal a community revelling in its new-found importance and increasingly adept at staging literary festivals; there would even seem to have been some kind of standing arrangement with local citizens who were prepared to loan ornaments and costumes for occasions such as these. (2)

The guest the college was expecting in the summer of 1566 was none other than Cardinal Giovanni Francesco Commendone, one of those most closely involved in the whole question of the Imperial succession as it affected Poland and Bohemia. Two years previously, he and his fellow cardinal

Provinz der Gesellschaft Jesu im Zeitalter der konfessionellen Auseinandersetzung, Quellen und Forschungen aus dem Gebiet der Geschichte ns 2 (Paderborn, etc.: Schöningh, 1981). See also the comments of Jerome Nadal SI on the University student population in a letter sent from Vienna on 8 May 1555: «Son los schólares 200 más o menos y lo que paresce mucho quasi todos son estrangeros" (Archivum Romanum Societatis Iesu (= ARSI), Epp. NN. 59, 138 [259]r-141[262] ${ }^{\mathrm{v}}$ $\left[\mathrm{n}^{\circ}\right.$ 73(31)] at $139[260]^{\mathrm{v}}$, repr. in Epistulae P. Hieronymi Nadal Societatis Iesu ab anno 1546 ad $1577(=E N)$, ed. Fridericus CERVÓs SI, 5 vols (Madrid: A. Avrial, 1898-1962), I: 1546-1562 (1898), Monumenta Historica Societatis Iesu (MHSI) 13, 299-306, letter 77, at 303).

(2) Unsigned letter from the Upper German Province to Rome, Dillingen, 1 July 1565 (AHSI, Germ. 139, 293a[158]r-293h $\mathrm{h}^{\mathrm{V}}$ at $\left.293 \mathrm{a}^{\mathrm{v}}-293 \mathrm{~b}[159]^{\mathrm{v}}\right)$; four-monthly letter signed simply "Erasmus", Dillingen, 22 January 1565 (ARSI Germ. 139, 286[113(4)]r-288[121(sic)] $]^{\mathrm{V}}$ at 187v). The first of these has a very full description of the use of Greek, Latin, and Hebrew poetry as part of the décor at a literary festival. 
Stanisław Hozyusz (Hosius) had been instrumental in bolstering the Catholic cause in the East by helping to establish a Jesuit mission to Poland, and he had continued ever since then to warn Rome of the urgent need to support Jesuit efforts in southern Germany, describing these to Pius IV in 1562 as "gran seruitio di questa santa sede». (3)

Commendone had spent the winter of 1565-6 travelling the roads between Trent, Augsburg, and Dillingen. (4) The purpose of this shuttle diplomacy was quite clear: he had been instructed to proceed to Augsburg, there to oppose by every means at his disposal any attempt on the part of the second so-called Diet of Augsburg to obtain a further measure of tolerance for Lutherans. The Diet had been convened by Emperor Maximilian, known to be secretly sympathetic to Protestant Reform. Commendone was also directed to ensure that the Elector of Cologne, Count Friedrich von Wied, who still persisted in the hope that some sort of accommodation might be possible with the heretics, was persuaded to take the oath and make the profession of faith prescribed by Trent. Commendone was also given overall responsibility for seeing that any episcopal sees that fell vacant in the meantime were filled by those loyal to Rome. (5)

(3) Rome, Bibliotheca Apostolica Vaticana (BAV), MS Barb. Lat. 5798, repr. in Nuntius Commendone, 1560 (Dezember)-1562 (März), ed. Adam WANDRUSKA, Nuntiaturberichte aus Deutschland nebst ergänzenden Aktenstücken II/ii (Graz \& Cologne: H. Böhlaus, 1953), 50-66, doc. 66 , at 52 .

(4) Stanisław ROSTOWSKI SI, Lituanicarum Societatis Iesu historiarum libri decem, ed. Ivan MARTYNOV SI (Paris \& Brussels: Victor Palmé, 1877), 1112 409; Stanisław ZAŁESKI SI, Jezuicki $w$ Polsce, 5 vols (11 parts) (Lwów: Drukarnia Ludowa [I-III] and Krakow: W. L. Anczyc [IV-V], 1900-6), I/i-ii, passim; Mario SCADUTO SI, L'epoca di Giacomo Lainez 1556-1565, 2 vols, Storia della Compagnia di Gesù in Italia III-IV (Rome: La Civiltà Cattolica, 1964-74), II. 310-11; Paulus RABIKAUSKAS SI, "Die Gründungsbulle der Universität Vilnius (30. Oktober 1579): Vorgeschichte, Ausstellung und Bedeutung", Archivum Historiae Pontificiae (Rome), XVI (1978), 113-70 at 121 ff.; Jan KOREWA SI, "Les débuts de la Compagnie de Jésus en Pologne 1549-1564", Archivum Historicum Societatis Iesu (Rome), XXXIV (1965), 3-35.

(5) See the instruction sent to Commendone from Rome, 27 February 1566 (Città di Castello, Archivo Graziana-Margherini, MS 15, 162r-v, repr. in Nuntius Biglia, 1565-1566 (Juni): Commendone als Legat auf dem Reichstag zu Augsburg 1566, ed. Ignaz P. DENGEL, Nuntiaturberichte aus Deutschland nebst ergänzenden Aktenstücken II/v (Vienna \& Leipzig: Hölder-Picher-Tempsky, 1926), 56-71, doc. 18. 
In the event, not all of these enterprises ended happily. Although the Diet broke up at the end of May 1566 without issuing any firm recommendations, Von Wied, for one, resigned his see, unrepentant, in 1567, and the following year, the Protestants persuaded Maximilian to allow the free practice of the Lutheran faith. But in the high summer of 1566, these reverses were still in the future and Commendone's course of action was clear. The detailed briefing he received from the new Pope, Pius V, reminded him that his natural allies in this struggle for hearts and minds were Duke Albrecht of Bavaria, the Spanish ambassador, and the fledgling Jesuit communities in the region. Indeed, Jesuit luminaries of the stature of Nadal, Ledesma, and Peter Canisius were on hand to lend their weight to Nuncio Biglia's campaign at the Imperial Court, as was the founder of the Dillingen College, Otto Truchsess von Waldburg, who had left Rome in late February in order to attend the Diet and whose activities in the region were directly subvented by Rome. ${ }^{(6)}$

As soon as he arrived in Dillingen for consultations at the beginning of June, Commendone, ever keen to ensure a high level of Latin learning in the colleges, dioceses, and monasteries he visited, ${ }^{(7)}$ hastened to make common cause with the Catholic faithful in the most public way possible by attending, along with Archduke Albrecht, Nuncio Biglia, and the founder himself, a performance of a play at the college Nadal had characterized some ten years earlier as «un propugnáculo de la fe». ${ }^{(8)}$ In two letters, written

(6) BAV, MS Cod. Urb. Lat. 1040, 188r-v [1040/11, 3r-v].

(7) See Michael MAYR, "Cardinal Commendones Kloster- und Kirchen-Visitationen von 1569 in den Diöcesen Passau und Salzburg», Studien und Mitteilungen aus dem Benediktiner-und Cisterzienser-Orden (Würzburg), XIV (1893), 385-98, 567-89.

(8) ARSI, EPp. NN. 59, at 139v. The Archduke was to prove one of the most assiduous enthusiasts for Jesuit plays: see Friedrich SCHMIDT, "Ein Festspiel der Münchener Jesuitenschule im XVI. Jahrhundert", Forschungen zur Kultur-und Literaturgeschichte Bayerns (Ansbach \& Leipzig), III (1895), 12-32. The 1566-67 Annual Letter of the Dillingen College, signed "Antonius Flander" and dated 1 October 1567, singles out Cardinal Truchsess's pride in his college's plays and dialogues, saying that he always made every effort to be present at them (ARSI, Germ. 140, $85[8(245)] \mathrm{r}-88[11(248)]^{\mathrm{V}}$ at $85^{\mathrm{V}}$ ). Otto Truchsess and his family had a tradition of service to the houses of Württenburg and Habsburg, as well as close connexions with the episcopal court at Dillingen: see Georg GRUPP, Oettingische Geschichte der Reformationszeit (Nördlingen: Reichle, 1894), and Virginia M. E. DEMARCE, "The official career of Georg III Truchsess von Waldburg: A 
from Augsburg over a space of just ten days by Nadal to the Jesuit General Francisco Borja in Rome, we can glimpse a sense of the importance this occasion had for these leaders of the Bavarian Catholic community, with their references to «la representatione ... che si fara là [i. e. in Dillingen] dinanzi all Reverendissimj legato, Augustano, et Nuncio» and to the Legate's journey to Dillingen, where he and Father Ledesma «uerrano a far' la pentecoste [5-8 June] in Dilinga doue si recitarà la tragedia ... et parechi epigrami à questi Reverendissimi Cardinali, et al Nuncio, et a monsignor lancilloto etc et forse anchora uerra il Reverendissimo Cameracense». (9) The Annual Letter written that autumn and signed by Christoph Ziegler SI on behalf of the Rector confirms that the Bishop of Cambrai was indeed present at the performance and furnishes yet more detail of the founder's attachment to his college and the steady stream of dignitaries whom he persuaded to grace the college with their presence.

Cum Dilingae est [Otto Truchsess], nullus ad eum Princeps accedit (accedunt autem plurimi) quem ad Collegium nostrum non adducat, ut hac ratione nostra rectius studia exteri intelligant ... Vno e[t] eodem tempore Cardinalem Commendonum Sedis Apostolicae à latere Legatum, Archiepiscopos Moguntinum et Treuerensem, qui Romani Imperij sunt electores praecipuj, unà cum Archiepiscopo Cameracensi, alijsque uiris primarijs ad templum nostrum adduxit, quos diuinis peractis officijs, quae integrè illi audierunt, generatim primum omnes, et Praesules deinde singulos Hebraicis, Graecis et latinis carminimus [ sic] à quodam ex societate compositis et per selectos pueros recitatis, excipiendos curauit, quibus etiam Tragedia non minus pia quam docta eiudem Reverendjssimi nostri sumptibus instructa, per discipulos scholae nostrae exhibita fuit. ${ }^{(10)}$

study in the administration of religious policy by a Catholic government during the first years of the Reformation", unpublished doctoral dissertation, Stanford University, 1966, 13.

(9) Letters of 11 and 21 May 1566 (ARSI, EPp. NN. 62, 156[90]r-157v at 156r and 165[96]r$166[97]^{\mathrm{V}}$ at 165 r, both repr. in $E N$ III $(1902), 122-4$, letter 391, at 123, and 140-44, letter 398, at 140-1. Scipione Lancilotti, canonist to Commendone and later created Cardinal by Gregory XIII, had been sent by Pius V to Archduke Albrecht and to the Emperor. The Bishop of Cambrai in 1566 was Maximilian de Walhain.

(10) Although the Jesuits were later to become disenchanted with Von der Leyen, archbishop of Trier from 9 March 1566 until his death in February of the following year, both he and his Mainz colleague Daniel von Brendel (elected 23 August 1555, died 22 March 1582) were at 
Details of the background to this play, as well as the documents cited here, are already in the public domain. ${ }^{(11)}$ But I have cited them here in extenso for a reason : these accounts focus on the local concerns of this particular Jesuit college and of those who publicly identified with it and them by being in the audience for the occasion. Let us now turn, more briefly, to two other Jesuit plays of which details have already been published.

Towards the end of that same century and some three hundred kilometers to the north-west, the college founded in 1561 in the strategically important city of Mainz at the confluence of the Main and the Rhine, twice staged plays on the biblical story of Ahab and Jezabel, taken from the third and fourth books of Kings. We do not know who wrote the piece that the Jesuits put on there in 1592 even though the text survives in at least three manuscripts, in Paderborn, Koblenz, and Cologne, a fact which may indicate that it was also performed in other German colleges. ${ }^{(12)}$ A fourth copy, recorded by Müller as being in the Münster Paulinum was probably destroyed by Allied bombing in World War II. (13) But the other play on this story, which was probably performed at Mainz in 1595 and again in Würzburg in 1611, survives in at least eight manuscripts. The one copy that is to be found today in Germany

this juncture seen by Commendone as the staunchest of allies. Both had been urged by Pius $\mathrm{V}$ to give the nuncio's mission their full support, just as they had his predecessor Canisius in November 1565. Given the international nature of the Jesuit studium, most of the cast were probably from Bohemia.

(11) Nigel GRIFFIN, "Lewin Brecht, Miguel Venegas, and the school drama: Some further observations", Humanitas (Coimbra), XXXV/XXXVI (1983-84 [1985]), 19-86 at 64-71.

(12) Details of these were originally provided by: Fritz REDIGER, Zur dramatischen Literatur der Paderborner Jesuiten, dissertation, University of Münster, 1935 (Emsdetten: H. \& J. Lechte, 1935), 7; Paul BAHLMAnN, Jesuitendramen der niederrbeinischen Ordensprovinz, Beiheft zum Centralblatt für Bibliothekswesen 15 (Leipzig: Otto Harrassowitz, 1896; repr. Nendeln, Liechtenstein: Kraus Reprint Limited, 1968), 119; Johannes MÜLLER SI, Das Jesuitendrama in den Ländern deutscher Zunge vom Anfang (1555) bis zum Hochbarock (1665), 2 vols, Schriften zur Deutschen Literatur 7-8 (Augsburg: Benno Filser, 1930), II. 52; and Wilhelm RICHTER, "Paderborner Jesuitendramen von 1592-1770", Mitteilungen der Gesellschaft für Deutsche Erziehungs- und Schulgeschichte (Berlin), IV (1894), 5-16.

(13) See Nigel GRIFFIN, Two Jesuit Ahab dramas, Exeter Hispanic Texts 13 (Exeter: University of Exeter, 1976), xiv, and, for further details and discussion of other possible performances, Jean-Marie VALENTIN, Le théâtre des jésuites dans les pays de langue allemande: Répertoire chronologique des pièces représentées et des documents conservés (1555-1773), 2 vols, Hiersemanns Bibliographische Handbücher 3/i-ii (Stuttgart: Anton Hiersemann, 1983-4), I. 
is in the same Cologne collection that includes the 1592 piece as well as dramatic treatments of the stories of two of kings of Judah, Manasseh and Zedekiah; it bears the legend, written in a seventeenth-century hand (fol. $\mathrm{B}^{\mathrm{v}}$ ): "Probabile existimo sequens Drama exhibitum Moguntiae aut Herbipoli eo tempore quo Philippus \& ferdinandus (postea Elector Coloniae) fratres Bauariae Ducis Moguntiam \& Herbipolim visitarunt cum ambos iuuenes essent, (? puto) inter annum 161590 \& 1600».

The date of the performance of the third play to which I should like to draw attention is unknown, but it almost certainly dates from the early years of the seventeenth century. Preserved in a manuscript in the Historisches Archiv der Stadt in Cologne (MS Univ. Akten 1058, formerly Univ. IX. 661) alongside twenty-two others, written in a variety of hands, and most of them treating themes we know, from Valentin and others, to have been popular in Jesuit studia in the sixteenth and early seventeenth centuries, it is entitled Tragoedia sacra Hierosolyma eversa per Nabvchodonosorem. A note on the first folio of the manuscript, written in a seventeenth-century hand (fol. Ar), describes the collection as being of "Tragoediae, Comoediae et Dramata pro Gymnasium trium Coronarum Societatis Jesu Coloniae ex variis theologiae studiosorum scriptis sub annum 1640 collecta». The play, then, was performed at the Cologne college, yet another 150 kilometers or so further to the north and west of Mainz. Occupying thirty-nine folios (150r-188v) and running to some sixteen hundred lines, the text and its stage-directions make it clear that this was a highly dynamic production, with great emphasis on stage business. It was also a play with a clear, local political message.

During the later sixteenth century, Cologne had acquired a reputation as a crucible of heterodox thought and political dissent. We have already noted that one Elector, Count Friedrich von Wied, was forced out of office; two others, Hermann V von Wied (Elector 1515-47) and Gebhard Truchsess von Waldburg (Elector 1577-83 and the nephew of the Otto Truchsess we just encountered as founder of the Dillingen college) were also charged with 
Lutheranism and removed, Gebhard having attempted to secularize Cologne and make it a free religious city only to be excommunicated by Gregory XIII in 1583 when he married, according to the Lutheran rite, his mistress Countess Agnes von Mansfeld. (14) The events that followed, as Gebhart, with the support of the Calvinistic Count Palatine, Johann Casimir, and of William of Orange, took up arms against his Wittelsbach successor Ernst of Austria, led to the co-called War of Cologne, a particular bloody affair which saw disaffected and unpaid Spanish troops from the Netherlands drafted in to sack and loot the towns and villages that supported Gebhard. (15)

Many of those who watched Hierosolyma eversa would have recalled the events of the 1580 s only too vividly. The play, with its emphasis on the twin themes of rebellion and punishment, clearly delivered a reminder that was as much political as it was theological. Although widespread devastation of town and countryside had eventually secured tenure of the Electorate by cadets of the Bavarian house and hence both the continuity of Catholicism in the region and a Catholic majority in the College of Electors, the events of 1609 to 1616 show beyond doubt that many independently-minded citizens of Cologne still felt a deep attraction for a possible anti-Habsburg alliance centering on the ill-fated Frederick V Elector Palatine and his young English bride, the Princess Elizabeth. ${ }^{(16)}$ The Jesuits were naturally in the forefront

(14) F. SEIBERT, "Zwischen Kaiser und Papst: Kardinal Truchsess von Waldburg und die Anfänge der Gegenreformation in Deutschland", unpublished doctoral dissertation, University of Berlin, 1943.

(15) Max LOSSEN, Der Kölnische Krieg: Vorgeschichte 1565-1581 (Gotha: F. A. Perthes, 1882); August FRANZEN, "Die Durchführung des Konzils von Trient in der Diözese Köln", in Das Weltkonzil von Trient: Sein Werden und Wirken, ed. Georg SCHREIBER, 2 vols (Frieburg im Breisgau: Herder, 1951), II. 267-94 at 271-2; Leonhard ENNEN, Geschichte der Stadt Köln: Meist aus dem Quellen des Kölner Stadt-Archivs, 5 vols (Cologne, etc.: L. Schwann, 1863-80), V: Zeit der Gegenreformation, 80-95 120-9 366-80; Friedrich REIFFENBERG SI, Historia Societatis Iesu ad Rhenum Inferiorem e MSS codicibus, principum, urbiumque diplomatis, et authoribus synchronis nunc primum eruta, atque ad historiam patriae ex occasione illustrandam accommodata, I (Cologne: Franz Wilhelm Joseph Metternich, 1764), Book VIII, Chapters 8-9 (209-20); ClausPeter Clasen, The Palatinate in European History 1555-1618 (Oxford: Basil Blackwell, 1963; revised edn 1966).

(16) REIFFEnBERG, Historia, Book XV, Chapter 1 (498); Cicely V. WEDGWOOD, The Thirty Years War (London: Jonathan Cape, 1938); Frances YATES, The Rosicrucian Enlightenment (London: Routledge \& Kegan Paul, 1972). 
of the opposition to any such development, and the message of Hierosolyma eversa, with its mayhem and its on-stage executions of the rebels, is clear and uncompromising. Those who flirt with rebellion against an absent «lawful» (Habsburg) monarch and conspire with the pro-Palatinate cabal against the true religion represented by the Bavarian Elector chosen to replace Gebhard will suffer the full Aeschylean horror of the fate that befalls the central character of the play, Sedecias, and his entourage. Their palaces and cities will be sacked and razed to the ground, as much of Cologne had been in the 1580s, and as Jerusalem was in the sixth century BC when the Babylonian hordes descended upon it; they themselves will be summarily executed as were the anti-Yahwist counsellors who ignored the warnings of Hieremias; and all that they hold dear will be destroyed before their very eyes. They will be left amid the ruins of their cause and their city, as is Sedecias in the play, ranting and raving in a blind fury while the victorious monarch and his loyal henchmen jeer at their fall and their impotence.

We have here, then, three performances, separated by some fifty years and by nearly five hundred kilometers. At first sight, they seem to have little in common with each other beyond their being staged in Jesuit colleges by Jesuit pupils, their obeying standing orders to the effect that such pieces should be written and staged exclusively in Latin (an order generally more honoured in the breach than in the observance), and their being tailored to the particular local religious and political concerns of the college where they were staged. The scholars who first drew attention to the existence of these three plays were, it would seem, quite unaware of any other possible connexion between them. ${ }^{(17)}$

Yet it happens that these three performances have a great deal in common. Two of them were written by Jesuit Fathers teaching in Portugal and had

(17) See, for example, Josef KUCKHOFF, "Das erste Jahrhundert des Jesuitenschauspiels am Tricoronatum in Köln», Jabrbuch des Kölner Geschichts-Vereins (Cologne), X (1928), 25-49; MÜLLER, Das Jesuitendrama. 
already been staged there before they arrived in Germany, and the third was supervised by an exiled dramatist from that same Portuguese Province.

The Mainz Ahab drama of 1595 is an adaptation of the Tragoedia cui nomen inditum Achabus of the best-known early dramatist of the Portuguese Province, Miguel Venegas. In addition to the Cologne manuscript mentioned above, there are manuscript copies in Portugal (two in Lisbon, and one each in Coimbra and Évora), France (in the Jesuit archives at Chantilly, outside Paris, where Venegas was active from November 1563 to February 1566, the copy of his Saul Gelboaeus contained in that same manuscript indicating that it, if not Achabus, had also been staged in Rome, in the Collegio Germanico), at Messina in Sicily (where manuscript play exchanges with Portugal are emerging as an intriguing possibility)(18) and at Perugia, and even, as Américo da Costa Ramalho discovered over forty years ago, in New York. (19) The play, which was transcribed and edited in 1976 by the present author alongside a second, anonymous Jesuit piece on the same subject from the Castile Province, is about to appear in a proper scholarly edition prepared by another contributor to this volume, Maria Margarida Lopes Miranda, who has already published widely on the play and on Portuguese Jesuit drama more generally. ${ }^{(20)}$

(18) See the characteristically cautious but intriguing remarks of Manuel José de Sousa BARBOSA, "Luzes e mistérios no teatro jesuítico: BPE, Cod. CVIII/2-7, fols 61r-85v: O Nabuchodonosor de Stephanus Tuccius? Interpelações de um texto truncado", Euphrosyne (Lisbon), XXXI (2003), 415-26.

(19) "Um manuscrito de teatro humanístico conimbricense», Humanitas (Coimbra), XIII/XIV (1960-61), I-VII b, repr. in his Estudos sobre a época do Renascimento (Coimbra: Instituto de Alta Cultura, Centro de Estudos Clássicos e Humanísticos anexo à Faculdade de Letras da Universidade de Coimbra, 1969), 333-45; also COSTA RAMALHO, "Eborae et Novi Eboraci», Humanitas (Coimbra), XV/XVI (1963-64), 434-35.

(20) See also her pilot studies : "Teatro jesuítico: Miguel Venegas, dramaturgo e mestre de retórica", in A retórica greco-latina e a sua perenidade (Coimbra, 11-14 de Março 1997), ed. José Ribeiro FERreira, 2 vols (Porto: Fundação Eng. António de Almeida, 2000), II. 655-69, and "Teatro bíblico novilatino: A Tragédia de Acab de Miguel Venegas", Humanitas (Coimbra), XLVI (1994), 351-71. Margarida Miranda's forthcoming edition is based on her 2002 Coimbra doctoral dissertation, "Miguel Venegas e o nascimento da tragédia jesuítica», which also incorporates significant discoveries made by Julio ALONSO ASENJO, of the University of Valencia, concerning Venegas's later years after he left the Society of Jesus: "Reencuentro con el $M^{\circ}$ Miguel Venegas: Su Comedia en la fiesta del santísimo sacramento", Cuadernos de Filología (Valencia), Anejo L (2002), 1-23 (see also http://parnaseo.uv.es/Ars/teatresco/textos/ComediaMVenegas.htm). 
Tragoedia sacra Hierosolyma eversa per Nabvchodonosorem, meanwhile, was also originally written in Portugal, and by Venegas's star pupil, the Lisbon-born Luís da Cruz (1542-1604). Entitled in the 1605 edition of da Cruz's plays Sedecias, Tragoedia de excidio Hierosolymae per Nabucdonosorem, it had been played in October 1570 at the Coimbra college in the presence of the sixteen-year-old King Sebastião, who eight years later was to perish along with the flower of the Portuguese nobility at the battle of Ksar el-Kébir. The considerable degree to which the play was adapted for performance in Cologne to emphasize local issues has been studied at length elsewhere. ${ }^{(21)}$

The final performance, that at Dillingen in 1566, attended by so many of the big hitters prominent in the protracted local struggle against Lutheranism (and I have included so much detail of that campaign in order to emphasize those particular local concerns), was of a play that was not of Jesuit authorship, the Euripus sive de inanitate omnium rerum, written by an Antwerp-born Franciscan, Livinus Brechtus, or Brechtanus, and first published in the author's adopted city of Leuven by Bathenius in 1549.(22) Yet here, too, there is a Portuguese connection, for the man drafted in from Augsburg - that same "quidam ex societate» singled out in the Annual Letter from Dillingen cited above - so that he might write some of the incidental material to be recited on this occasion and help to orchestrate the performance was none other than Venegas himself. As Nadal informed Borja on 11 May 1566 from Augsburg: «Il P. Vanegas è arrivato qua sono quatro o cinco

(21) GRIFFIN, "A Portuguese Jesuit play in seventeenth-century Cologne», in Studies in the sixteenth-and seventeenth-century theatre of the Iberian Peninsula, ed. Michael J. RUGGERIO, Folio: Essays on Foreign Languages and Literatures 12 (New York: Folio, 1980 [1981]), 46-69 at 56-61.

(22) On the importance of this play see Fidel RÄDLE, "Die Bühne des Euripus», Maske und Kothurn (Vienna), XVIII (1972), 197-206; Jean-Marie VALENTIN, "Aux origines du théâtre néolatin de la Réforme catholique: L'Euripus (1549) de Livinus Brechtus", Humanistica Lovaniensia (Louvain), XXI (1972), 81-188, repr. in VALENTIN, Theatrum catholicum, XVI ${ }^{-}$XVII ${ }^{e}$ siècles, Études Allemandes (Nancy: Presses Universitaires de Nancy, 1990), 131-206; RÄDLE, "Aus der Frühzeit des Jesuitentheaters: Zur Begleitung einer Edition lateinischer Ordensdramen», Daphnis: Zeitschrift für Mittlere Deutsche Literatur (Amsterdam), VII (1978), 403-62; and, for information on Jesuit performances of it, GRIFFIN, «Lewin Brecht», 47-76. 
giorni, et l'hier' l'altro l'habbiamo mandato in Dilinga... In questo mezzo puotra aiutar' a far' alchuni uersi per la representatione dell'Euripo che si fara là... Il giorno stesso che arriuò là, fece alchunj Epigrami all'Imperatore, al Reverendissimo de Augusta, all Illustrissimo legato et al ducca de Bauiera, et hoggi li hauemo mostrato al Augustano, et li contentano molto.»(23) It may be of some interest that one of several surviving manuscript copies of Venegas's own Tragoedia cui nomen inditum Saul Gelboaeus, first performed by the pupils of the Coimbra Colégio das Artes on Sunday 9 July 1559, is to be found today in Dillingen, in the Studienbibliothek, in a miscellany (Hs 219) which once belonged to the most prolific of all Jesuit dramatists, Jakob Gretser (1562-1625) and which also contains a copy of Euripus, and that the play was also staged at the Avignon college in 1570, perhaps as a way of celebrating the apparent end of the local difficulties the Jesuits had encountered the previous year. The Rector at the southern French studium was the distinguished diplomat Antonio Possevino, who had been a good friend of Venegas and invited him to stay for some time at the college. (24)

Nowhere, either in the surviving manuscripts of the texts or in the contemporary accounts we have cited, is there even the merest hint of a Portuguese connection. Someone reading these plays without recourse to the secondary literature would never suspect that they were the work of writers from outside the cultural miniclimats in which they were performed.

One reason we know of these links is that the relatively small dramatic output of the Portuguese Province has been studied closely by Professor

(23) ARSI, Epp. NN. 62, 156r-157v at 156r, repr. in EN III (1902), 122-4, letter 391, at 123.

(24) Anton DÜRRWÄCHTER, "Aus der Frühzeit des Jesuitendramas nach Dillingen Manuskripten", Jahrbuch des Historischen Vereins Dillingen (Dillingen), IX (1897), 1-54 at 4; Nigel GRIFFIN, "Miguel Venegas and the sixteenth-century Jesuit school drama", Modern Language Review (London), LXVIII (1973), 796-806 at 801; GRIFFIN, "Some Jesuit theatre manuscripts", Humanitas (Coimbra), XXIII/XXIV (1971-2), 427-34 at 433; VALENTIN, Répertoire, I. 2, $\mathrm{n}^{\circ} 11$; Marcel Chossat SI, Les Jésuites et leurs oeuvres à Avignon (Avignon: F. Seguin, 1896), 1-25; Henri FOUQUERAY, Histoire de la Compagnie de Jésus en France des origines à la suppression (1528-1762), 5 vols (Paris: A. Picard, 1910-25), I. 434-40; GRIFFIN, "Lewin Brecht», 74-6. 
Américo da Costa Ramalho, his Coimbra pupils, and the pupils of those pupils. There are many other regions of Europe, some of them much more productive in terms of plays, where a good deal of the necessary spadework still remains to be done. The German-speaking lands of Europe have been minutely trawled and magnificently chronicled by Professor Jean-Marie Valentin of the Sorbonne, happily a contributor to this present volume, and we also have, for those same lands, the 7500-page edition of printed play summaries, or periochae, compiled by Elida-Maria Szarota. Elsewhere, however, the picture is still very patchy and for some countries, most notably France, there is no overview of Jesuit production for the whole period up to the dissolution of the Society in the second half of the eighteenth century. ${ }^{(25)}$

Valentin has shown, by using contemporary correspondence, manuscript college histories, secondary literature, manuscript catalogues past and present, and the surviving texts of plays, that it is possible, even if exhausting and painstakingly slow, to trace a play staged at a particular college back to its author and college of origin. The evidence he furnishes in his Répertoire not only demonstrates beyond doubt that plays written and performed in one college or in one Province of the Society frequently found their way to other colleges and other Provinces, but it also suggests many avenues of possible research. An entry such as «1566. Munich (octave de Pâques). David et Goliath. Texte latin manuscript peut-être cod. Dil. 219, ff. 194-246 : Goliat sive David vincens, Cf. également infra, Mayence, 1587», sets more than one hare going. ${ }^{(26)}$

(25) See the account of the secondary literature by GRIFFIN, "Jesuit Drama: A guide to the literature", in I gesuiti e i primordi del teatro barocco in Europa: Roma, 26-29 ottobre 1994, Anagni 30 ottobre 1994, XVIII Convegno Internazionale del Centro Studi Medioevale e Rinascimentale, ed. Miriam CHIABÒ \& Federico Doglio (Rome: Centro Studi Medioevale e Rinascimentale, 1995), 465-96. Some advances have been made since then, but not many.

(26) VAlEnTIN, Répertoire, I. 7, n 49. One such hare concerns the whole family of plays on the story of David and Goliath. See, in addition to the two alluded to here: Vienna 1645 and Dillingen 1648 (VALENTIN, Répertoire, I. 172 182, n ${ }^{\text {os }} 1420$ 1491); Pułtusk 1609-22? and Lublin 1637 (Jan Okoń, Dramat i teatr szkolny: Sceny jezuickie XVII wieku, Studia Staropolskie 26 (Wrocław, Warsaw \& Krakow: Zakład Narodowy imienia Ossolińskich, 1970), 358, 365); Cahors 1622 (Louis Desgraves, Répertoire des programmes des pièces de théâtre jouées dans les collèges en France (1601-1700), École Pratique des Hautes Études, $2^{\text {nd }}$ s, IV ${ }^{\mathrm{e}}$ section: Sciences 
We are also beginning to identify some of the ways in which literary texts travelled from one college to another. In a recent essay, Valentin talks of Stefano Tuccio's Christus Iudex, as having been staged at the Collegio Romano in 1569 «avant de faire le tour des grands collèges jésuites européennes». (27) The question of just how such a tour might happen and of how far, when it does, the play may be adapted to embody local concerns and capture the attention of those present, is not without interest. I have yet to find archival evidence (though, of course, it may exist) of copies of plays being sent with a covering letter from one college to another. But there are plenty of examples of dramatists who, as in the case of Venegas, carried manuscript copies of his works with them on their travels and, in his case, it seems that he may even have kept some of his manuscripts when he left the Society and returned to Spain to teach (and, incidentally, write plays), first at the University of Salamanca and then at his alma mater at Alcalá de Henares. Another channel of dissemination came in the form of fair copies of literary compositions, sometimes expensively bound for the occasion (and accordingly more likely to survive), presented to a distinguished college guest as a memento of the festival he had witnessed. Such presentation copies were often gifted or bequeathed to the dedicatee's local Jesuit college, once he had returned home. This, we know, happened in the

\footnotetext{
Historiques et Philologiques 6: Histoire et Civilisation du Livre 17 (Geneva: Droz \& Paris: Champion, 1986), 40); Rome 1632 and 1647 (Bruna FILIPPI, Il teatro degli argomenti: Gli scenari secenteschi del teatro gesuitico romano: Catalogo analitico, Bibliotheca Instituti Historici SI 54 (Rome: Institum Historicum SI, 2001), 131-40 196-200); Zsolna (Sillein) 16494 (Géza STAUD, A magyarországi jezsuita iskolai szinjátékok forrásai I: 1561-1773/ Fontes ludorum scenicorum in scholis S.I. Hungariae, 4 vols, Magyar Tudományos Akadémia Irodalomtudományi Intézete 1-4 (Budapest: A Magyar Tudományos Akadémiai Könyvtárának Kiadása, 1984-94), II. 465).

(27) Jean-Marie VALENTin, Les jésuites et le théâtre (1554-1680): Contribution à l'bistoire culturelle du monde catholique dans le Saint-Empire romain germanique, La Mesure des Choses (Paris: Éditions Desjonquères, 2001), 337. The play has been the subject of two recent studies by Mirella SAULINI, in one of which there is a discussion of adaptations for performance in different venues: «La città nel teatro, il teatro per la città: Le tragedie del P. Stefano Tuccio SJ", in Vita cittadina nel teatro fra Cinque e Seicento, Anagni 4-5-6 settembre 1998, XXII Convegno internazionale del Centro Studi Medioevale e Rinascimentale, ed. Miriam CHIABÒ \& Federico DOGLIO (Rome: Edizioni Torre d'Orfeo, 1999), 281-96, and "Un nuovo manoscritto del Christus iudex del P. Stefano Tuccio SI: La 'versione' messinese e la 'versione' romana”, Giornale Storico della Letteratura Italiana (Turin), CLXXVI (1999), 196-221.
} 
case of the plays of Venegas that were presented in the summer of 1561 to Próspero Publícola de Santa Cruz, Bishop of the Cretan see of Quissamo in partibus infidelium and Pius IV's legate to the Portuguese Court, even though the manuscript which eventually found its way into the Hispanic Society of New York, where it was discovered by Costa Ramalho, may not, in his judgement, be the actual volume presented to the visitor, but rather a copy of it. ${ }^{(28)}$ Then there are the cases of the volumes which, removed from Jesuit colleges by occupying forces or rapacious individuals, eventually found their way into libraries and archives. An example would be the manuscripts, including one with plays by Grzegorz Knapski (1564-1638), that were taken from the Poznan college by the Swedish diplomat and bibliophile Claes Rålamb during the hostilities sparked by Charles X's 1655 invasion of the Polish-Lithuanian republic and which were later deposited in the library at Uppsala. ${ }^{(29)}$ The printing of plays, most famously in the case of Luís da Cruz's Tragicae comicaeque actiones from the Lyon presses of Horace Cardon in 1605, also made individual texts available for performance as well as schoolroom use. (30) Decisions in principle to authorize the

(28) COSTA RAmalho, Estudos, 338-40. King João III of Portugal was similarly presented with a copy of the pieces he had heard at Lisbon in 1556: Diogo de Bairros from Lisbon, ?January 1557, Litterae quadrimestres (=LQ), ed. Mariano LECINA SI, 7 vols (Madrid: A. Avrial, 1894-1932), $\mathrm{V}$ (MHSI 59), 18. There are recorded cases of requests for copies from other members of an audience: "Multi legendi, aliqui exscribendi eius, copiam petierunt»: Cabrera from Murcia, 29 June $1557, L Q$ V. 260, letter 70. The manuscript history of the Granada college in southern Spain refers (entry for 8 May 1583) to the making of copies as standard practice (Madrid, Archivo Histórico Nacional, MS Jesuitas Libro 773, p. 9), and one of the volumes in the Real Academia de la Historia, also in Madrid (MS 349), may well be just such a presentation volume.

(29) See Lidia WINNICZUK, "Humour in Jesuit school drama and the Roman comedy", in $A n$ tiquitas graeco-romana ac tempora nostra: Acta congressus internationalis habiti Brunae diebus 12-16 mensis Aprilis MCMLXVI, ed. Jan BURIAN \& Ladislav VIDMAN, Československá Akademie věd Kabinet pro Studia Řecká, Římská a Latinská Historický Ustav (Prague: Academia, 1968), 301-11. An excellent example of a traveller and emissary acting as an agent of international artistic diffusion is furnished by the recent study of the important library collected by Płotr Dunin-Wolski, bishop of Płock, during his embassy to the Spanish Court (1561-1573), now in the Jagellion Library in Krakow: see Volsciana: Katalog renesansowego księgozbioru Piotra Dunin-Wolskiego, biskupa płockiego, ed. Andrzej OBREBSKI, Biblioteca Iagellonica: Fontes et Studia 9 (Krakow: Księgarnia Akademicka, 1999).

(30) It might prove useful to trace the many copies of this volume in Jesuit libraries and library inventaries, and then to examine the post-1605 playlists for the colleges concerned, 
printing of material displayed, recited, or performed at ludi litterarii date from the very earliest teaching years of the Society. (31)

Yet our detailed knowledge of some of these channels of dissemination and of possible links between one play and the next is still largely serendipitous. If we are to be confident that we understand the many ways in which plays travelled and one came to influence another, we need, I suggest, a properly international database that can make the raw data available to future scholars and obviate some at least of the time-consuming labour that has characterized so much of what those gathered in Coimbra have been trying to do over the course of the past thirty years or so. Such a database would enable us to recognize and then examine potential links. What, for example, is the relationship between the Saul com filiis Abachi superatus tragoedia given at Caen in Normandy in 1628, and first recorded over a century ago by Paul de Longuemare, of which a printed play summary (or perioche) survives in the Bibliothèque Nationale de France, and the many other Saul, Ahab, and Jezabel plays that we know were staged throughout Jesuit Europe?(32) Or, again, is Fr László Lukács laconic footnote to the account of the November 1583 performance of a Comaedia Philautii contained in the notes amassed by the Rector of the college at Kolozsvár (Claudiopolis, Cluj), Jacob Wujek, "Fortasse ab aliquo magistro collegii claudiopolitani composita», accurate? Or may that play be related, directly or indirectly, to

with a view to establishing how many of da Cruz's plays were performed after the volume was printed, and where.

(31) E.g. Ignatius Loyola to Nadal, Rome, 8 February 1554, Monumenta Ignatiana, s. I, Epistolae et instructiones, ed. Mariano LECINA SI \& Vicente AGUSTİ SI, 12 vols (Madrid: G. López del Horno, 1903-11), VI (MHSI 33), 306, letter 4149; Laínez to Adriano Adriani in Louvain, Rome, 25 November 1556, Lainii Monumenta, ed. Ephrem ASTUDILLO SI, 8 vols (Madrid: G. López del Horno, 1912-17), I (MHSI 44), 167-8, letter 278. There was some discussion, however, of the need to correct student compositions, possibly at headquarters, prior to publication (see, for example, the queries sent from the Castile Province to Rome (? 1569), Madrid, Biblioteca Nacional, MS 2307, fol. 181v).

(32) "Le théâtre scolaire à Caen aux XVII et XVIII siècles", Réunion des Sociétés des Beaux-Arts des Départements (Paris) XVIII (1894), 1052-87 at 1057. See also Abbé Marie-Joseph-AugusteIsidore MASSELIN, "Le collège des jésuites de Caen", Revue Catholique de Normandie (Évreux), VII (1897), 303-11 377-88 463-79; VIII (1898), 171-86 207-14, at VII. 476; also, more recently, Desgraves, Répertoire, 38. 
the piece of the same name written by Father Pedro Pablo de Acevedo and staged in the Seville college in southern Spain in 1565?(33)

We know from the experience provided by using Valentin's Répertoire just how many avenues are opened up by having a vast mass of detailed information brought together in a single place. My suggestion is that we now use this gathering, so generously arranged by Prof. Sebastião Tavares de Pinho and his Coimbra colleagues, to embark upon the creation of a similar database, but this time one that covers the whole of the Society of Jesus.

Clearly, such an undertaking could not be contemplated by a single individual working alone. Nor would it be practicable to collect and collate the information on record-cards in the way we all had to in the pre-computer age. Nor would it be sensible to envisage the final dissemination in print of such a database. We shall need to take advantage of modern technology to establish a free exchange of data and to ensure that we are in a position to update the database at regular intervals in the light of fresh discoveries. Making the latest version of the database available on the Internet free of charge would also have the advantage that we might be able to count on the collaboration of colleagues (from Latin America, India, Eastern Europe, and so on) who have at present few if any additional financial resources for research. A good example of the practicability of Internet publication in this field is the work done over the past few years by Julio Alonso Asenjo and his colleagues at the University of Valencia in Spain.

The first task will be to establish just how much detail we wish to include about a play text, an author, a manuscript, a printed play programme, and

(33) Monumenta Antiquae Hungariae, ed. Ladislaus LUKÁCS SI, II: 1580-1586, MHSI 112 (Rome: Institutum Historicum SI, 1976), 611-12, n 240; STAUD, A magyarországi jezsuita iskolai szinjátékok forrásai, III. 240-1. There is quite possibly a cat's cradle of influences here. See, for example, Vicente PICón GARCíA, "La comedia Philautus de Acevedo: Sus deudas al Terencio cristiano (Acolastus de Gnaphaeus y Samarites de Papeus)", in Congreso internacional sobre humanismo y Renacimiento: Actas (León: Universidad de León, 1998), 599-609. The most recent edition of the Acevedo play is by Antonio CASCÓN DORADO and Vicente PICÓN GARCÍA in Teatro escolar latino del siglo XVI: La obra de Pedro Pablo de Acevedo SI, I: Lucifer furens, Occasio, Philautus, Charopus, ed. PICón GARCía et al., Bibliotheca Latina (Madrid: Ediciones Clásicas, 1997), 295-423. 
an account of a performance. To that end, I shall in the spring of 2005 be circulating those present as well as other scholars in the field who could not be with us in Coimbra, asking them to complete a questionnaire giving their views. Then we shall have to identify on-line cross-referencing systems that will perform the functions classically discharged in printed volumes by multiple indexes. Next, we shall need to design the database. Once those fundamental building blocks are in place, we should be able to proceed to identifying collaborators and sharing out the donkey work in such a way as to make the project compassible. After that, we can move to identifying possible sources of funding, since an injection of funds might allow us to engage graduate students part-time in the project, thus helping them to finance their own studies while maintaining the necessary momentum to complete the initial database by a particular dealine, say in 2010.

A small first step towards this dissemination of reference material on the Internet will be a second edition, updated and revised of my own little bibliography of secondary literature. This will become available on line during the course of 2006.(34)

(34) Jesuit school drama: A checklist of critical literature. The second edition, running to well over 3000 entries, will incorporate material published since 1985 as well as revising all the entries from the first edition of 1976 and its 1986 supplement. I am grateful to the publisher of those two volumes, Grant \& Cutler Ltd of London, now part of the Tamesis imprint owned by Boydell \& Brewer of Woodbridge, Suffolk, for permission to publish the second edition under my own imprint on the Internet. 
(Página deixada propositadamente em branco) 


\section{Série}

\section{Documentos}

Imprensa da Universidade de Coimbra

Coimbra University Press

2006

- $\mathrm{U}$

C • 